\title{
PREVALENCE IN ITALY OF ANTIBODIES TO A NEW HUMAN PAPOVAVIRUS (BK VIRUS)
}

\author{
M. Portolani, A. Marzocchi, G. Barbanti-Brodano and M. La Placa \\ Institute of Microbiology, University of Bologna, Via San Giacomo 12, \\ I-40126 Bologna, Italy
}

BK VIRUS is a papova-like virus isolated by Gardner et al. (1971) from the urine of a patient on immunosuppressive therapy for kidney transplantation. Viruses with similar characters have been isolated from brain tissue from several cases of progressive multifocal leukoencephalopathy (PML) (Padgett et al., 1971; Weiner et al., 1972). BK virus is antigenically related to simian virus 40 (SV40) (Gardner et al., 1971; Takemoto and Mullarkey, 1973), but is antigenically distinct from polyoma virus and human wart virus (Gardner et al., 1971). It agglutinates human group-O erythrocytes and the haemagglutinin is firmly associated with the virion (Mäntyjärvi, Arstila and Meurman, 1972). It was shown recently to cause a malignant transformation of hamster cells (Major and Di Mayorca, 1973), thereby raising the question of a possible role in human oncogenesis.

Infection with BK virus in man is common in England (Gardner, 1973); haemagglutinationinhibiting (HI) and complement-fixing antibodies were found in all age groups. We investigated 453 healthy people in Italy by the $\mathrm{HI}$ test, and also by the fluorescent-antibody (FA) technique to detect antibodies to other structural components of the virion.

\section{MATERIALS AND METHODS}

Virus and cells. BK virus was kindly supplied by Dr S. D. Gardner and was grown in Vero cells. Growth and maintenance media were Eagle's minimum essential medium supplemented with $2.5 \%$ foetal bovine serum. One week after infection of the cultures the medium was changed and after a further 7-10 days' incubation, when cytopathic effects were clearly evident, cells and medium were frozen and thawed once, treated for $2 \mathrm{~min}$. in a Branson ultrasonic disintegrator, and centrifuged at $800 \mathrm{~g}$ for $10 \mathrm{~min}$. to sediment cellular debris. The supernatant fluid had a titre of 2048 to 40,768 haemagglutinating units (HAU) per ml, and was used as antigen in the haemagglutination (HA) and HI antibody tests. SV40 was grown in Vero cells in the same way as BK virus.

Sera. Serum specimens were obtained from healthy donors, ages 19-65 years, in the Blood Centre of the University Hospital, Bologna. Other sera were collected from healthy children and young people, aged 6 months-18 years, in Milan.

Haemagglutination. HA and HI antibody tests were performed in disposable plates by the microtitre method (Sever, 1962). Serial two-fold dilutions of BK virus were made in 0.05-ml amounts of phosphate-buffered saline (PBS), $p \mathrm{H} \mathrm{7.2}$. Human type-O erythrocytes, from healthy donors, were washed three times and suspended to a concentration of $0.5 \%$ in PBS. One volume of PBS and two volumes of $0.5 \%$ erythrocytes were added to each virus dilution. Plates were incubated at $+4^{\circ} \mathrm{C}$ and the HA titre was read 4 hours later, when control erythrocytes in PBS only had completely sedimented. The highest dilution of antigen giving complete haemagglutination was considered to contain 1 HAU.

Haemagglutination-inhibition. Sera were heated at $56^{\circ} \mathrm{C}$ for $30 \mathrm{~min}$. and treated with $\mathrm{NaIO}_{4}$ to remove non-specific inhibitors. Serial, two-fold dilutions of serum, from 1 in 4 to 1 in 8192 , were made in $0.05 \mathrm{ml}$ amounts of PBS. One volume of PBS containing $8 \mathrm{HAU}$ of antigen was added to each serum dilution and the mixtures were kept at room temperature for 1 hour. After this time, two volumes of $0.5 \%$ erythrocytes were added, the plates were incubated at $+4^{\circ} \mathrm{C}$ for 4 hours, and the HI-antibody titres were read. From the correlation

Received 1 May 1974; accepted 20 May 1974.

J. MED. MICROBIOL.-VOL. 7 (1974) 
found between HI and FA tests, an HI-antibody titre of 128 or greater was regarded as positive.

Preparation of antiserum to BK virus. Guinea pigs were given subcutaneous injections of the supernatant fluid from infected cell cultures. These were repeated four times at weekly intervals and animals were bled 5 days after the last injection. The immune serum had an HI antibody titre of 1280 .

Immunofluorescence. Vero cells grown on glass coverslips were infected with BK virus or SV40. Four days later, the cells were fixed in acetone and stained by the indirect FA technique, with fluorescein-conjugated goat antiserum to human immunoglobulins (Hyland). Human test sera were examined at a 1 in 2 dilution only. Specificity controls included

TABLE I

The frequency of haemagglutination-inhibiting $(H I)$ and fluorescent antibodies to $B K$ virus and the distribution of HI-antibody titres in different age groups

\begin{tabular}{|c|c|c|c|c|}
\hline \multirow{3}{*}{$\begin{array}{l}\text { Age group } \\
\text { (years) }\end{array}$} & \multirow{2}{*}{\multicolumn{2}{|c|}{$\begin{array}{l}\text { Proportion (and percentage) } \\
\text { of sera with }\end{array}$}} & \multicolumn{2}{|c|}{$\mathrm{HI}$-antibody tests } \\
\hline & & & \multirow{2}{*}{$\begin{array}{c}\text { Range of } \\
\text { titres } \dagger\end{array}$} & \multirow{2}{*}{$\begin{array}{l}\text { Percentage of } \\
\text { sera with } \\
\text { titres of } 512 \\
\text { or greater }\end{array}$} \\
\hline & HI antibody* & $\begin{array}{l}\text { fluorescent } \\
\text { antibody }\end{array}$ & & \\
\hline $\begin{array}{c}0-2 \\
3-5 \\
6-10 \\
11-15 \\
16-25 \\
26-35 \\
36-45 \\
46-55 \\
56-65\end{array}$ & $\begin{array}{l}22 / 46(47 \cdot 8) \\
38 / 61(62 \cdot 2) \\
57 / 75(76 \cdot 0) \\
21 / 27(77 \cdot 7) \\
34 / 41(82 \cdot 9) \\
47 / 74(63 \cdot 5) \\
39 / 51(76 \cdot 4) \\
28 / 46(60 \cdot 8) \\
19 / 32(59 \cdot 3)\end{array}$ & $\begin{array}{r}18 / 46(39 \cdot 1) \\
30 / 59(50 \cdot 8) \\
52 / 72(72 \cdot 2) \\
19 / 26(73 \cdot 0) \\
15 / 19(78 \cdot 9) \\
20 / 29(68 \cdot 9) \\
20 / 25(80 \cdot 0) \\
14 / 22(63 \cdot 6) \\
9 / 13(69 \cdot 2)\end{array}$ & $\begin{array}{l}128-8192 \\
128-8192 \\
128-4096 \\
128-2048 \\
128-2048 \\
128-2048 \\
128-1024 \\
128-1024 \\
128-1024\end{array}$ & $\begin{array}{l}36 \cdot 9 \\
42 \cdot 6 \\
42 \cdot 6 \\
37 \cdot 0 \\
46 \cdot 3 \\
33 \cdot 7 \\
29 \cdot 4 \\
26 \cdot 0 \\
21 \cdot 8\end{array}$ \\
\hline Total & $305 / 453(67 \cdot 3)$ & $197 / 311(63 \cdot 3)$ & & \\
\hline
\end{tabular}

BK-virus-infected cells stained with guinea-pig antiserum to BK virus and fluoresceinconjugated rabbit-antiserum to guinea-pig IgG (Hyland).

\section{RESULTS}

The distribution of $\mathrm{HI}$ and fluorescent antibodies to BK virus at various ages is illustrated in table I. A high frequency of antibodies was found in the Italian population and there was substantial agreement between the results of the two tests. Antibodies were already prevalent by the age of 2 years $(47.8 \%$ by the $\mathrm{HI}$ and $39.1 \%$ by the FA test) and maximum frequency was reached by $16-25$ years $(82.9 \%$ by $\mathrm{HI}$ and $78.9 \%$ by FA). A small decrease occurred after the age of 45 years although the prevalence was still high. The highest serum titres (8192) were found in children under 5 years old; HI antibody titres of 512 or greater were found in all age groups, and most commonly between 16 and 25 years. A slight sex difference in the distribution of antibodies was observed in adults: antibodies were found in $79.2 \%$ (HI test) and $77.9 \%$ (FA test) of males and in $62.5 \%$ (HI test) and $56.5 \%$ (FA test) of females.

Table II illustrates the correlation obtained between the $\mathrm{HI}$ antibody titres and a positive FA test in sera that were examined by both methods. Almost all the sera with HI antibody 
titres of 256 and greater were also positive by the FA test; $75 \%$ of sera with a titre of 128 were positive. On the other hand, the majority of the sera with $\mathrm{HI}$ antibody titres of 64 or less were negative by the FA test. It was for this reason that sera were accepted as positive for BK virus antibodies by the HI test only when the titre was 128 or higher. The specificity of the FA test for detecting BK-virus antibody in human serum was confirmed by the identical nuclear fluorescence obtained in BK-virus-infected cells stained by either human sera or specific guinea-pig antiserum.

Ten sera that were positive for BK-virus antibody by both the HI and FA tests, obtained from persons over 56 years of age who had not been vaccinated against poliomyelitis, were also tested on SV40-infected cells; all gave positive fluorescence.

TABLE II

Correlation, between haemagglutination-inhibiting ( $H I)$ antibody titres and a positive fluorescent-antibody (FA) test in human sera

\begin{tabular}{c|c}
\hline HI-antibody titres & $\begin{array}{c}\text { Number (and percentage) of sera } \\
\text { with HI antibody giving } \\
\text { a positive FA test }\end{array}$ \\
\hline 8192 & $2 / 2(100)$ \\
4096 & $10 / 10(100)$ \\
2048 & $21 / 21(100)$ \\
1024 & $37 / 37(100)$ \\
512 & $48 / 51(94)$ \\
256 & $32 / 35(91)$ \\
128 & $18 / 24(75)$ \\
64 & $12 / 29(40)$ \\
32 & $6 / 31(19)$ \\
16 & $2 / 22(9)$ \\
8 & $2 / 12(16)$ \\
$<8$ & $1 / 31(3)$ \\
\hline
\end{tabular}

\section{Discussion}

Our results confirm that antibodies against this human papova-like virus are common in man. The prevalence in Italy of BK-virus antibody is very similar to that found in England (Gardner, 1973), and to that of the closely related JC virus in the United States (Padgett and Walker, 1973).

The discrepancy between the HI and FA tests in some of our sera is most probably due to incomplete removal of non-specific inhibitors of HA. However, it is possible that the FA test is somewhat more sensitive because it also detects structural virus components that do not participate in the HA reaction.

BK virus is antigenically related to SV40, and SV40 antibodies have been found in persons given early batches of poliovaccine that were contaminated with SV40 (Gerber, 1967). However, our finding of such antibody in older persons who have no history of poliovaccination suggests that these are actually due to the widespread prevalence of BK virus in the population (Shah et al., 1971).

\section{SUMMARY}

Sera from 453 healthy persons of various ages were examined by haemagglutinationinhibition and by immunofluorescence for antibodies to BK virus, a new human papovavirus. Both tests showed that antibody was common in the population and that a majority of the infections probably occurred in early childhood.

This research was supported by grants from the Consiglio Nazionale delle Ricerche, Rome, Italy. The excellent technical assistance of Mr L. Franchi and the helpful advice of 
Miss Luisa Benni are gratefully acknowledged. We thank Dr M. L. Profeta for providing sera of children and young adults.

While this paper was in the press, a paper by Shah et al. (1973, J. infect. Dis., 128, 784), which reports results very similar to ours, came to our notice.

\section{REFERENCES}

Gardner, S. D., Field, A. M., Coleman, D. V. ANd Hulme, B. 1971. New human papovavirus (B.K.) isolated from urine after renal transplantation. Lancet, 1, 1253.

GARDNER, S. D. 1973. Prevalance in England of antibody to human polyomavirus (B.K.). Br. med. J., $1,77$.

GERBER, P. 1967. Patterns of antibodies to SV40 in children following the last booster with inactivated poliomyelitis vaccines. Proc. Soc. exp. Biol. Med., 125, 1284.

MAJOR, E. O. AND DI MAYORCA, G. 1973. Malignant transformation of BHK-21 clone 13 cells by BK virus, a human papovavirus. Proc. natn. Acad. Sci. USA, 70, 3210.

Mäntyjärvi, R. A., Arstila, P. P. AND Meurman, O. H. 1972. Hemagglutination by BK virus, a tentative new member of the papovavirus group. Infect. Immun., 6, 824.

PadgetT, B. L. AND WalkeR, D. L. 1973. Prevalence of antibodies in human sera against JC virus, an isolate from a case of progressive multifocal leukoencephalopathy. $J$. infect. Dis., 127, 467.

Padgett, B. L., WAlker, D. L., ZuRhein, G. M., ECKroade, R. J. AND Dessel, B. H. 1971. Cultivation of papova-like virus from human brain with progressive multifocal leukoencephalopathy. Lancet, 1, 1257.

SEVER, J. L. 1962. Application of a microtechnique to viral serological investigations. $J$. Immun., 88, 320.

Shah, K. V., Ozer, H. L. Pond, H. S., Palma, L. D. and Murphy, G. P. 1971 . SV40 neutralizing antibodies in sera of US residents without history of polio immunization. Nature, Lond., 231, 448.

TAKeMOTO, K. K. AND MUllaRKeY, M. F. 1973. Human papovavirus BK strain: biological studies including antigenic relationship to simian virus 40. J. Virol., 12, 625.

Weiner, L. P., Herndon, R. M., Narayan, O., Johnson, R. T., Shah, K. V., Rubinstein, L. J., PReziosi, T. J. AND Conley, F. K. 1972. Isolation of virus related to SV40 from patients with progressive multifocal leukoencephalopathy. New Engl. J. Med., 286, 385. 